\section{PENGGUNAAN ARSIP FILM PROPAGANDA \\ ROMUSHA MASA PENDUDUKAN JEPANG SEBAGAI SUMBER BELAJAR SEJARAH PESERTA DIDIK}

\author{
Dio Yulian Sofansyah ${ }^{\mathrm{a}, \mathrm{b}}$ \\ krietienk45@gmail.com

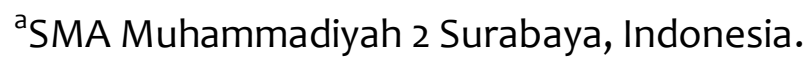 \\ ${ }^{\mathrm{b}}$ Universitas Negeri Malang, Indonesia.
}

\begin{abstract}
With regard to content about the Japanese occupation in history lectures in universities, most of the available material is in textual form, especially in history textbooks. Meanwhile, there is an abundance of archival videos available about this topic that could be used as media or learning materials in classroom learning. This research aims to offer some ideas in using the propaganda films produced during the Japanese occupation as alternative learning material. By doing so, resources learners are expected to realize the teaching and learning process to be varied, fun, easy to understand, able to stimulate imagination, share events that previously abstract in a short time and can bring learners through space and time indirectly because the film media in accordance with the material, needs and objectives proses teaching and learning.
\end{abstract}

Keywords: historical films, Japanese propaganda, romusha

Arsip adalah dokumen administrasi dari pekerjaan kantor yang berbentuk arsip, formulir, surat, atau laporan yang disimpan secara periodic, teratur, dan berencana karena mempunyai suatu kegunaan agar setiap kali diperlukan dapat diakses dengan cepat dan mudah ditemukan kembali. Begitu pula Sularso Mulyono mengungkapkan bahwa arsip adalah Penempatan kertas-kertas dalam tempat penyimpanan yang baik menurut aturan yang telah ditentukan terlebih dahulu sedemikian rupa sehingga setiap dokumen apabila diperlukan dapat ditemukan kembali dengan mudah dan cepat. Dari pernyataan di atas dapat disimpulkan bahwa arsip adalah kumpulan dokumen yang disimpan secara periodik dan sistematis dengan Langkah-langkah tertentu yang sudah ditetapakan dalam ilmu kearsipan dan bertujuan untuk mempermudah melakukan penelusuran data kembali untuk mendapatkan informasi yang telah lalu. Bicara mengenai penelusuran fakta sejarah, tanpa 
adanya dokumen arsip akan sangat sulit untuk mendapatkan data untuk fakta sejarah yang diinginkan (Absor, 2017).

Ada bermacam-macam dari bentuk arsip di antaranya berupa arsip audio visual berupa film. Tulisan ini berfokus pada arsip film pada materi pendudukan Jepang yang dahulu banyak digunakan sebagai media propaganda dari berbagai aspek, salah satunya menggunakan media film yang menayangkan propaganda romusha. Peneliti menambil arsip film propaganda yang diunggah pada situs www.openbeelden.nl yang banyak memberikan arsip-arsip audio visual masa pendudukan Jepang. Peneliti menganggap bahwa hal ini sangat relevan menjadi sumber dan media pembelajaran, karena video-video propaganda pada masa pendudukan Jepang dapat mengungkapkan bangaimana cara dan upaya Jepang dalam menarik perhatian bangsa Indonesia untuk membantunya dalam menghadapi perang Asia Timur Raya menghadapi Sekutu.

Sejarah merupakan ilmu terkait peristiwa masa lalu yang memiliki bukti konkret berupa, tulisan, foto, rekaman, dokumen, arsip, benda, artefak dan lain sebagainya. Secara etimologi, kata arsip memiliki makna yang sama dengan istilah archeon yang berasal dari bahasa Yunani Kuno. Istilah archeon sendiri memiliki beberapa arti seperti kekuasaan, tempat utama, permulaan dan asal, kedaulatan, dan kantor, namun istilah ini lebih tepat diartikan sebagai permulaan atau asal (Pramudyo, 2016). Sejarawan bertugas menafsirkan sumber sejarah menjadi sebuah kronologi kejadian dari masa lalu menjadi kesatuan yang utuh sesuai fakta-fakta yang terjadi.Dialog yang tak berujung antara masa lampau, masa sekarang, dan masa yang akan datang, merupakan gambaran bahwa adanya proses interaksi tanpa henti antara seorang sejarawan dengan fakta sejarah (Aman, 2011). Sejarah bersifat berkesinambungan karena adanya peran manusia didalamnya. Bagaikan kepingan sisi mata uang, sejarawan dan fakta sejarah merupakan sisi yang saling melengkapi untuk menjadikan sejarah unik namun juga berbentuk sebagai ilmu. Fakta sejarah merupakan dokumen yang membuat sejarawan tetap hidup.

Pendidikan dan pembelajaran merupakan dua hal yang berbeda, namun kedua hal tersebut sangat erat kaitannya dan tidak dapat dipisahkan bagai kepingan mata uang dengan sisi yang berbeda. Dalam proses mendidik umunya pembelajaran akan berada di dalamnya, sedangkan dalam melakukan proses pembelajaran belum tentu terdapat proses mendidik didalamnya. Pendidikan merupakan proses belajar mengajar agar orang dapat berfikir secara arif dan lebih bijaksana, sedangkan pembelajaran adalah proses belajar untuk mendapatkan ilmu dan pengertahuan tertentu. Dari pengertian dasar diatas dalam mewujudkan cita-cita bangsa, pendidikan adalah salah satu cara yang utama. Pendidikan Sejarah memiliki peran yang sangat besar dalam mewujudkan citacita bangsa. Sebagai sarana pendidikan, pengajaran sejarah termasuk pengajaran normatif, karena tujuan dan sasarannya lebih ditujukan pada segi normatif yaitu segi nilai dan makna yang sesuai dengan tujuan pendidikan (Alfian, 2011). Rumusan tujuan pendidikan nasional seperti yang dirumuskan dalam UU No. 20 Tahun 2003 tentang Sistem Pendidikan Nasional bahwa: "Pendidikan adalah usaha sadar dan terencana untuk mewujudkan suasana belajar dan proses pembelajaran agar peserta didik secara aktif mengembangkan potensi dirinya untuk memiliki kekuatan spiritual 
keagamaan, pengendalian diri, kepribadian, kecerdasan, akhlak mulia, serta keterampilan yang diperlukan dirinya, masyarakat, bangsa dan negara" (Susilo, 2016).

Pembelajaran di masa kini tidak dapat terlepas dari perkembangan teknologi. Arus globalisasi yang sangat pesat membawa pembelajaran ke arah modernitas yang memudahkan proses belajar mengajar. Segala informasi yang dibutuhkan terkait bahan ajar tersedia di Internet sehingga secara tidak langsung segala kebutuhan dari peserta didik dapat dipenuhi. Namun kemudahan mengakses segala informasi dapat menyesatkan karena tidak semua informasi pada internet dapat dipertangung jawabkan. Sebagai seorang pendidik sekaligus pengajar sejarah akan dihadapkan pada perkembangan teknologi yang pesat dan terus berkembang.

Beberapa penelitan terdahulu yang memiliki kesamaan tema, menjadi bahan referensi bagi penulis dan memperkaya bahan kajian pada penelitian. Pertama, penelitian Fadila (2020) yang menunjukkan bahwa pendayagunaan arsip film melalui kegiatan pemutaran film keragaman lokal konten budaya Jawa pada Grahatama Pustaka Balai Layanan Perpustakaan DPAD DIY memberikan pengaruh positif dalam melestarikan nilai budaya dan sejarah melalui film. Perkenalan budaya dan sejarah dilakukan dengan cara yang cukup berbeda yaitu dari adanya film dokumenter (Fadilla, 2020). Hasil penelitian ini senada dengan penelitian sebelumnya yang dilakukan oleh Santoso (2019) yang mengindikasikan bahwa pengemasan ulang data atau dokumen arsip harus menarik dan sesuai dengan kaidah-kaidah pengarsipan agar bisa menjadi strategi yang sangat efektif sebagai sarana sosialisasi dan edukasi kepada pengguna arsip.

Meskipun arsip, termasuk arsip film, memiliki potensi yang luar biasa untuk edukasi dan sosialisasi seperti yang diindikasikan oleh dua penelitian sebelumnya (Fadila, 2020 dan Santoso, 2019), namun hasil penelitian Aryani (2017) menunjukkan bahwa pengarsipan film di Indonesia belum dilakukan secara baik, karena belum terpusatnya tipe-tipe dokumen yang akan diarsipkan. Arsiparsip tersebut tersimpan di berbagai lembaga pemerintahan maupun swasta.

Dari penelitian terdahulu dapat disimpulkan bahwa penggunaan media arsip film dapat memberikan dampak positif diberbagai bidang. Dalam dunia pendidikan pada masa sekarang yang erat dengan perkembangan teknologi digital, pendidik dituntut untuk dapat memanfaatkan media digital dalam proses belajar mengajar. Arsip film sejarah dapat digunakan sebagai salah satu media belajar peserta didik. Arsip film ini dapat dikorelasikan dengan keterampilan abad 21 sebagai salah satu upaya peningkatan kompetensi sumber daya manusia dimasa sekarang.

Proses belajar mengajar dengan materi masa pendudukan Jepang banyak menyuguhkan materi propaganda. Arsip terkait propaganda tersebut sangat beragam, salah satunya berupa film propaganda yang disebarkan secara luas pada masa pendudukan Jepang. Artikel ini bertujuan untuk menawarkan penggunaan arsip film propaganda sebagai sumber belajar sejarah tentang masa pendudukan Jepang. Arsip film propaganda pada masa pendudukan tersebut dapat diakses dengan bebas sehingga dapat digunakan sebagai sumber belajar sekaligus media belajar, sehingga peserta didik dapat menganalisis secara langsung melalui situs yang disediakan. 


\section{METODE}

Penelitian ini menggunakan metode kajian literatur, yang berupa serangkaian kegiatan yang berkenaan dengan metode pengumpulan data kepustakaan, menelaah dan mencatat, serta mengkaji bahan penelitian. Studi kepustakaan idilakukan oleh penulis dengan tujuan untuk mencari dasar pijakan dalam memperoleh landasan teori, kerangka berpikir, memberikan suatu gambaran hal-hal yang telah diketahui dan yang belum diketahui dari suatu fenomena khusus dan mengidentifikasi dari hasil-hasil penelitian terdahulu (Afiyanti, 2014).Artikel ini menawarkan sumber belajar baru pada peserta didik baik dalam tingkat sekolah menengah atas ataupun perguruan tinggi. Bentuk cara belajar ini dikarenakan masih banyaknya sumber belajar pada masa pendudukan Jepang yang masih bersifat bacaan dan hanya mengacu pada pamahaman buku teks yang didapatkan oleh peserta didik. Metode pengumpulan data menggunakan observasi. Menurut Riyanto (2010:96) observasi merupakan metode pengumpulan data yang menggunakan pengamatan secara langsung, ataupun tidak langsung. Data sejarah yang digunakan dalam artikel ini adalah data berupa film arsip propaganda pada masa pendudukan Jepang yang diupload oleh situs https://www.openbeelden.nl/ yang dapat diakses secara bebas. Situs ini berada dibawah naungan dari Nederlands Instituut voor Beeld en Geluid yang merupakan arsip budaya dan sebuah museum yang terletak di Hilversum, Belanda.

\section{HASIL DAN PEMBAHASAN}

\section{Propaganda Masa Pendudukan Jepang}

Imperialisme Jepang menggiring Indonesia pada kependudukan Jepang selama tiga tahun lamanya. Selama itu, untuk merebut hati rakyat Indonesia dan juga mengumpulkan dukungan sebanyak-banyaknya demi kemenangan perang, Jepang tidak hanya menggunakan strategi militer tetapi juga teknik-teknik propaganda. Propaganda dilakukan melalui kegiatan seni, sastra dan budaya dengan melibatkan sastrawan dan seniman Jepang untuk dikirimkan ke daerah-daerah pendudukan. Para sastrawan propaganda ini tergabung dalam kelompok Nanpochoyousakka (penulis yang dikirim ke selatan). Latar belakang mereka beragam mulai dari penyair, pengarang, kritikus, seniman, karikaturis dan lain sebagainya (Dewi dkk., 2015).

Dalam perkembangan seni pertunjukan dan kesusastraannya di Jepang di masa pendudukannya, memberikan pengaruh yang sangat pesat baik terutama pada seni sandiwara. Jepang menyadari bahwa kesenian sandiwara dapat menjadi modal utama dalam menyampaikan propaganda-propaganda anti Barat atau untuk mendukung Jepang mengalahkan Sekutu dalam Perang Dunia II. Tampaknya rakyat mudah dipengaruhi dengan menggunakan konsep pertunjukan ini. Penyampaian dan penampilan-penampilan secara langsung dapat segera direspon dan merasuk kedalam suasanan hati para penontonnya (Sofansyah, 2018). Dengan adanya upaya ini maka pertunjukan sandiwara dihidupkan lagi dan segala bentuk perfilman yang berbau Eropa dilarang keras, meskipun nantinya Jepang juga akan mendirikan perusahaan film untuk kepentingan propagandanya. 
Sulit untuk menemukan asal-usul dari istilah propaganda. Tetapi, ada sumber yang menyatakan bahwa kata itu mulai digunakan pada tahun 1622, ketika Paus Gregory XV mendirikan sebuah organisasi yang diberi nama Congregatio de Propaganda Fide. Organisasi ini memiliki tugas untuk menyebarkan agama Kristen Katholik di kalangan masyarakat non-Kristen. Dari sumber tersebut, "propaganda" secara azali diartikan sebagai organisasi yang mengirimkan atau menyebarkan pesan-pesan terhadap seseorang atau kelompok masyarakat. Setelah tahun 1622 propaganda tidak hanya diartikan sebagai organisasi, tetapi juga sebagai pesan yang disebarkan oleh organisasi. Dalam perkembangannya, pengertian propaganda juga berkaitan dengan berbagai teknik yang digunakan untuk menyampaikan pesan, seperti poster iklan, film dan tayangan-tayangan televisi (Yuliati, 2012).

Ide bahwa propaganda sangat penting untuk berperang berasal dari Nazi Jerman. Dibuktikan dengan eksisnya Pasukan Kebudayaan yang dipimpin Goebbels (Menteri Propaganda) pada masa Perang Dunia II. Instansi ini bertugas mengadakan propaganda terhadap musuh dan orang Jerman sendiri. Di Asia Tenggara, Jepang mengikuti contoh Jerman dan mengadakan Departemen Propaganda (Sendenbu) di dalam Gunseikanbu. Banyak budayawan Jepang (bunkajin) yang terkenal, seperti penulis, pelukis, penyair, juru foto, sutradara, penata musik, penulis komik dan lain sebagainya dikirim ke Asia Tenggara dan ditempatkan di Sendenbu. Mereka semua diberi dwifungsi. Fungsi pertama membuat materi propaganda untuk penduduk di daerah jajahan. Penulis mengarang cerita yang diterjemahkan untuk dibaca penduduk setempat. Pengubah musik membuat banyak lagu propaganda yang bersifat lokal. Pelukis mengambar poster dan kamishibai. Kamishibai adalah materi informasi untuk anak-anak yang mirip wayang beber. Banyak gambar yang dilukis sesuai dengan cerita, kemudian dipertontonkan kepada anak-anak seraya operator atau dalang menjelaskan ceritanya secara lisan. Karena biaya pembuatannya cukup murah dan pelaksanaannya gampang, kamishibai menjadi sangat populer dan cukup banyak dipakai di mana-mana. Tugas budayawan Jepang lainnya adalah memberi informasi kepada warga Jepang perihal kehidupan dan perkembangan daerah selatan. Mereka juga diminta memberi kesan banyak penduduk di daerah sana yang membantu Jepang. Dengan mengenal perkembangan di daerah jajahan, hati orang Jepang sendiri juga dibangkitkan (Kurasawa, 2016).

Masa pendudukan Jepang merupakan masa tersingkat eksploitasi bangsa asing yang pernah terjadi di Indonesia. Meski sesama bangsa Asia, namun sistem kolonialisme dan imperialism dari Jepang justru kian mencolok dan tidak ada bedanya dengan bangsa Eropa. Dorongan untuk menguasai dunia bersama Blok Sentral sangat besar. Upaya ini diwujudkan Jepang dengan terjun langsung ke dalam Perang Dunia II. Hal ini yang membuat Jepang memobilisasi penduduk di setiap daerah yang didudukinya ke arah kebutuhan perang. Upaya ini dirasa berhasil dengan menggunakan sistem propaganda.

Jepang sadar bahwa propaganda yang kasar akan menyebabkan reaksi negatif dari rakyat Indonesia. Jepang kemudian mensiasati propagandanya dengan menggabungkannya dengan kesenian-kesenian yang berkembang di Indonesia pada masanya. Oleh karena itu, perhatian Jepang 
adalah bagaimana meningkatkan efek propaganda tanpa merusak aspek-aspek hiburannya, meski fungsi sandiwara sebagai pertunjukan hiburan menjadi nomor dua. Hasilnya pemerintah Jepang tetap dapat melancarkan propaganda-propagandanya dengan tidak menghilangkan unsur-unsur seni atau artistik di dalamnya. Sasaran pokok propaganda Jepang ialah memobilisasi rakyat Indonesia demi upaya kemenangan perang Jepang dan menguasai Asia Timur Raya. Demi tujuan tersebut pemerintah Jepang merasa perlu untuk melakukan indoktrinasi atau memobilisasi rakyat Indonesia ke dalam misi Jepang dalam upaya memenangkan perang Asia Timur Raya, sebagai mana yang telah dicoba di Taiwan dan Korea. Pada tahun pertama pendudukan Jepang propaganda lebih berorientasi ideologis, dengan tujuan untuk memberitahukan secara propagandis bahwa Jepang ingin memberitahukan bahwa apa sebenarnya tujuan Jepang dalam keterlibatannya dalam perang dan dalam pendudukannya di Indonesia (Sofansyah, 2018).

Petugas sendenbu Jepang menyadari diantara upaya Jepang untuk memobilisasi masyarakat Indonesia melalui propanda, film adalah upaya paling besar dalam memberikan dampaknya. Pembuatan film propaganda untuk daerah pendudukan militer di Asia Tenggara hanya dilakukan di Jakarta. Sebab, fasilitasnya memang hanya tersedia di sana. Sebuah perusahaan film Jepang, Nippon Eigasha (disingkat Nichi'ei), ditugaskan memproduksi film di Jakarta. Eiga Haikyusha ditugaskan mendistribusikan film propaganda ke setiap daerah yang kuasai Jepang. Selain di Indonesia, pembuatan film sebagai alat propaganda juga diutamakan di Mancuria. Untuk itu didirikan Asosiasi Film Mancuria. Di sana dibuat film cerita yang sangat populer seperti "Shina no Yoru," yang mengambarkan persahabatan antara Tiongkok dan Jepang. Dengan alat dan bahan hasil sitaan tentara Jepang di Jakarta, Nichi'ei mempergunakan fasilitas perusahaan film Belanda yang bernama Multi Film, untuk memproduksi film propaganda Fasilitasnya jauh lebih baik dibanding buatan Jepang pada zaman itu (Kurasawa, 2016). Jepang akan mendatang film-film dari Jepang dan sekutunya negara. Film tersebut dibawa dari Jepang adalah film-film yang dianggap berguna untuk propaganda. Konten dari film biasanya, harus berisi moral ajaran dan indroktrinasi politik yang sejalan dengan keinginan pemerintah, dan film-film ini dikatagorikan sebagai film "kokusaku eiga" (film-film kebijakan nasional) (Erwantoro, 2010).

Untuk memproduksi film, dikirimlah sutradara, kameraman dan ahli rekam dari Jepang. Di Jakarta produksi pembuatan film dipusatkan kepada film berita dan film dokumenter, sementara pembuatan film cerita atau hiburan sangat sedikit. Film berita dibuat dengan memakai gambar yang telah dikirim dari seluruh Asia Tenggara. Film berita dibuat di Jakarta setiap dua minggu dengan panjangnya kurang lebih 10 menit. Film-film itu berjudul Jawa Nyusu (Maret-Desember 1943) dan Nanpo Hodo (Januari 1944-Agustus. 1945). Namun untuk film berita daerah lain di Asia Tenggara gambarnya diedit di Tokyo, kemudian dipasangi terjemahan dalam bahasa masing-masing daerah. Sesudah itu filmnya didistribusikan ke berbagai daerah dengan judul Daitoa Nyasa. Pada waktu itu film dokumenter yang disebut bunka eiga terasa sekali kental dengan nuansa propaganda (Kurasawa, 2016). 
Ada beberapa tema yang diutamakan untuk menggiatkan bekerja dan meningkatkan daya ekonomi, seperti "Bekerdja", "Romusha", "Karung Goni di Jawa", "Menanam Kapas", "Mari Menggandakan Hasil Jarak", "Penanaman Bibit", "Kerja Cembira", "Ubi Jalur", dan "Mengarap Sawah". Selain itu, ada juga yang menyerukan pertahanan tanah air, seperti "Pemakaran Tombak Bamboe", "Djagalah Tanah Djawa", "Pendjagaan Rakjat oentoek Membela Tanah Air", "Tentara Pembela", dan "Heiho Angkatan Laut". Selain itu, ada propaganda untuk menjaga kesehatan, seperti "Rajio Taiso" (gerak badan ikut siaran radio), "Kesehatan Badan", dan "Pembasmian Malaria". Ada yang bernuansa politik, seperti "Jawa no Zènchasetse" (Upacara Merayakan Hari Ulang Tahun Kaisar), "Menujoe ke Arah Mengambil Bagian Pemerintahan Dalam Negeri", "Indonesia Raya", dan "Toa no Yoi Kodomo" (Anak Baik Daitoa). Toa no Yoi Kodomo mengambarkan kehidupan anak-anak di sekolah (Kurasawa, 2016).

Lagu sering dipergunakan dalam film untuk mengantikan narasi. Mungkin karena lagu gampang dihafal dan berdampak besar seperti lagu iklan di TV yang sekarang. Selain film buatan lokal, film Jepang juga diimpor. Kebanyakan berupa film militer yang melukiskan pertempuran hebat dan ke menangan Jepang. Selain itu, ada juga film yang menggambarkan bagaimana Jepang menyelamatkan dan menjadi pelindung bangsa di kawasan Asia dari imperialism bangsa Eropa. Filmfilm ini bukan hanya dipertontonkan di bioskop, tetapi juga diputar oleh tim keliling. Tim itu membawa film dan alatnya dalam truk dan keliling. Kalau masuk ke desa, mereka memutar film di lapangan kosong dengan gratis. Kadang-kadang pemimpin besar seperti Sukarno juga ikut tur putaran itu dan memberi orasi sebelum film. Tur putaran biasanya menarik perhatian penduduk dan memancing banyak penonton datang. Bagi kebanyakan orang desa, menonton film adalah pengalaman baru (Kurasawa, 2016).

\section{Mobilisasi Penduduk Indonesia Melalui Romusha}

Romusha sendiri dalam Bahasa Indonesia diartikan sebagai pekerja paksa pada masa pendudukan Jepang. Namun pada masa pendudukan Jepang menyebutnya sebagai prajurit ekonomi atau barisan pekerja, karena berperan dalam pembangunan sarana infrastruktur dalam menghadapi perang Asia Timur Raya. Namun bagi bangsa Indonesia romusha tidak jauh berbeda dengan kerja rodi pada masa penjajahan Belanda. Romusha adalah tenaga kerja paksa baik laki-laki maupun perempuan. Tenaga kerja ini umumnya berumur sekira 16-40 tahun. Perekrutan romusha ini dimobilisasi mengunakan struktur pemerintahan yang paling rendah ditingkat kecamatan (son), desa (ku), dan rukun tetangga (Tonarigumi). Para romusha bekerja untuk Militer Jepang melalui aparat pemerintahan lokal dengan instruksi bersifat sukarela atau secara paksaan. Setiap tiga wilayah yang dibagi tiga pemerintahan militer, memiliki dan mengorgaisasi pekerja sebagai romusha. Namun pulau Jawalah yang memiliki tingkat mobilisasi penduduk paling tinggi unutk menjadi para pekerja romusha. Para pekerja romusa disebarkan ke wilayah yang menurut Kepala Pemerintahan Jepang sangat membutuhkan banyak pekerja seperti di wilayah Sumatera, Kalimantan, Jawa Bagian Selatan. Selainpenyebaran didalam negeri pekerja romusha ini juga dapat dikirim ke luar negeri seperti Singapore, Filipina, Malaysia, dan Birma. Tentu pengaturan suplai tenaga kerja dilihat melalui 
tingkat kebutuhan dan target yang ingin dicapai oleh Pemerintah Militer Jepang di ketiga wilyah administratif(Saputra, 2018).

Para peneliti sejarah pendudukan Jepang di Indonesia yang membahas romusha seperti Kurasawa, Sato, Raben, memberikan data pekerja romusha yang dikirimkan ke wilayah Asia Bagian Selatan dan Pasifik sebanyak kurang lebih 300.000 orang Jawa. Namun Kurasawa sendiri menggunakan dokumen arsip yang didapat dari pemerintah Jepang, dan mengungkap jumlah romusha yang dimobilisasi oleh Pemerintah Militer Jepang, mencapai jumlah 4 juta jiwa (Kurasawa, 1993). Menurut Kepala Militer Jepang di Pulau Jawa, Yamamoto, jumlah tenaga kerja yg dikirim jumlahnya hanya sekitar kurang lebih 140.000 sampai 160.000 orang (Nishijima dalam Herkusumo, 1982). Jumlah pengerahan tenaga kerja romusah sampai saat ini masih tidak pasti karena sulitnya menemukan arsip valid untuk pengerahan tenaga kerja massal di wilayah Indonesia. Apalagi antara jumlah romusha yang dikirim keluar Pulau Jawa, di dalam Pulau Jawa, romusha tetap dan romusha sementara, serta klasifikasi persis usia yang dipaksa bekerja, masih belum jelas (Saputra, 2018).

Diluar dari berbagai pendapat dan perdebatan mengenai jumlah romusha, kondisi para pekerja romusha sangat memprihatinkan. Melalui propagandanya, Jepang dapat menarik hati masyarakat Indonesia lalu memobilisasinya untuk kepentingan pemerintah pendudukanJepang. Pemanfaatan tokoh politik, film, pementasan sandiwara, pertunjukan lagu, dan berbagai media cetak pada masa itu mengakibatkan banyaknya masyarakat yang masuk mendaftar untuk menjadi tenaga romusha dengan sukarela.

\section{Arsip Film Propaganda Romusha sebagai Sumber Belajar}

Film merupakan salah satu media Jepang dalam mempropagandakan tujuannya menduduki wilayah Indonesia. Masyarakat Indonesia sudah mengenal film sejak masa kolonial Belanda sehingga daya tarik akan tontonan film sangat besar, terutama pada lapisan masyarakat atas. Meskipun Jepang juga menggunakan kesenian sandiwara sebagai media dalam propagandanya, industri perfilman juga dikembangkan agar terjadi pemerataan dalam tingkatan sosial terkait propaganda yang diberikan Jepang. Di awal masa pendudukannya, Jepang segera melakukan penyitaan di seluruh perusahaan film pada masa kolonial untuk melancarkan tugas dari badan propaganda atau Sendenbu sebagai alat untuk indoktrinasi politik di Indonesia.

Perusahaan perfilam di Jepang pertama kali dibentuk oleh pemerintah Jepang di Tokyo pada awal tahun 1941. Perusahaan tersebut adalah Nichi'ei yang bertindak sebagai perusahaan yang memproduksi film Jepang dan Eihai yang berperan sebagai perusahaan distribudi film Jepang. Diawal berdirinya kedua perusahaan tersebut masih belum memiliki cabang di daerah pendudukan. Ketika Jepang masuk dan menduduki Indonesia, segera dibentuk perusahaan film sementara bernama DJAWA EIGA KOSHA (Perusahaan Film Jawa) yang bertugas mengelola perusahaan film milik Belanda yang berhasil disita oleh Jepang. Namun atas dasar dari NAMPO EIGA KOSAKU YORYO (Propaganda Film di wilayah Selatan) maka kebijakan dari DJAWA EIGA KOSHA dialihkan ke Nichi'ei 
dan Eiha. Terlebih dengan dibukanya cabang kedua perusahaan tersebut di Jakarta maka DJAWA EIGA KOSHA dibubarkan.

Film-fllm Jepang secara hati-hati dipilih, dan hanya film-film yang terutama dianggap berguna sebagai bahan propaganda yang dimpor. Dengan kata lain, film impor adalah yang jelas mengandung ajaran moral dan indoktrinasi politik yang diinginkan pémerintah untuk dipertunjukkan bagi penduduk Jawa. Film yang bersinggungan dengan sistem pemerintahan disebut sebagai KOKUSAKU EIGA (film terkait kebijakan nasional) dan menerima perlakuan khusus dari pemerintah. Kebanyakan film Jepang yang dipertunjukkan di Jawa harus bersifat film kebijakan nasional tersebut. Film-flm yang dipertunjukkan di Jawa, yang judul serta isinya bisa penulis kenali, dapat dibagi ke dalam enam kategori berikut.

a. Film harus menekankan persahabatan antara bangsa Jepang dan bangsa-bangsa Asia serta peran dari Jepang dalam memajukan daerah koloni.

b. Film harus berisikan patriotisme dan pengabdian terhadap bangsa.

c. Film yang menunjukkan operasi militer dan menekankan kekuatan militer Jepang.

d. Film yang menekankan kejahatan dan kekejaman bangsa Barat.

e. Film yang menekankan moral berdasarkan nilai-nilai Jepang seperti pengorbanan diri, kasih sayang ibu, penghormatan terhadap orang tua, persahabatan yang tulus, sikap kewanitaan, kerajinan, dan kesetiaan.

f. Film yang yang memperlihatkan peningkatan produksi dan kampanye perang dan lainnya.

g. Lain-lain (Kurasawa 1993).

Film propaganda tersebut dipertontonkan di bisokop-bioskop hasil dari penyitaan Jepang pada awal pendudukannya, sehingga banyak masyarakat Indonesia yang dapat melihat film tersebut dengan membeli karcis. Pada masa kolonial Belanda telah ditetapkan bahwa gedung bioskop hanya boleh diisi pribumi sebanyak 10 persen, namun pada masa pendudukan Jepang aturan tersebut diperlonggar dengan memperbolehkan pribumi memasuki gedung bioskop sampai 50 persen. Hal ini agar penyebaran propaganda dapat menjadi efektif dan sasaran dari Jepang untuk memobilisasi penduduk Indonesia terutama Jawa dapat tersampaikan.

Arsip film propaganda yang diunggah pada situs www.openbeelden.nl banyak memberikan arsip-arsip audio visual masa pendudukan Jepang. Peneliti menganggap bahwa hal ini sangat relevan menjadi sumber dan media pembelajaran, karena video-video propaganda pada masa pendudukan Jepang dapat mengungkapkan bangaimana cara dan upaya Jepang dalam menarik perhatian bangsa Indonesia untuk membantunya dalam menghadapi perang Asia Timur Raya menghadapi sekutu. Dikatakan dalam web resmi tersebut bahwa: "Situs ini akan membuat kumpulan berita mingguan Jepang dari tahun 1941-1945 tersedia online mulai 1 September. Film-film ini digunakan sebagai propaganda di bekas Hindia Belanda (sekarang Indonesia), yang berada di bawah pendudukan Jepang dari tahun 1942 hingga 1945. Hak cipta (Jepang) telah berakhir, membuat filmfilm ini berada di domain publik dan tersedia secara terbuka secara online. Para peneliti, lembaga pendidikan, dan masyarakat umum sekarang memiliki kesempatan untuk melihat, mengunduh, dan 
menggunakan kembali film tersebut." (https://blog.openbeelden.nl/blog/2020/og/unieke-japansepropagandafilms-1942-1945-open-online-beschikbaar/)

Adanya situs resmi yang menyediakan film arsip propaganda pada masa pendudukan Jepang dapat dimanfaatkan sebagai sumber belajar peserta didik yag membahas masa pendudukan Jepang. Sebagai contoh terkait pembahasan tema romusha pda masa pendudukan Jepang dapat dilihat dari arsip video dengan judul sebagai berikut:

1) Disnipoen medan perang (6) yang terbit pada 1 Januari 1943. Film propaganda ini berdurasi sekitar 10 menit dengan produsernya Nippon Eigasha. Film propaganda ini menjelaskan tentang gubahan fragmentaris yang menampilkan kerjasama yang baik antara penjajah Jepang dan penduduk Indonesia.

2) Bekerdja yang terbit pada 1 Januari 1943. Film propaganda ini berdurasi sekitar 6 menit dengan produsernya Nippon Eigasha. Film Propaganda ini adalah lagu penyemangat untuk bekerja bagi masyarakat Indonesia yang dibawakan oleh paduan suara campuran dengan solois wanita dan pria.

3) Disnipoen Medan Perang (5) yang terbit pada 1 Januari 1943. Film propaganda ini berdurasi sekitar 9 menit dengan produsernya Nippon Eigasha. Film propaganda ini berisi tentang jurnal propaganda Jepang dengan topik sebagai berikut: Pembentukan masyarakat Jawa dalam Pengabdian kepada Rakyat, Peluncuran Kapal, Pameran Lukisan Indonesia, Penangkapan Ikan oleh Tentara Jepang, Penanaman dan Panen Kapas, Pengolahan Kapas di Pabrik Pemintalan, Pemeriksaan Panglima Angkatan Darat Jepang Harada.

4) Barisan Pekerdja yang terbit pada 1 Oktober 1943. Film propaganda ini berdurasi sekitar 9 menit dengan produsernya Nippon Eigasha. Film propaganda ini berisi tentang reportase sekaligus propaganda tentang perekrutan tenaga kerja Jawa untuk upaya perang Jepang. Meskipun pendaftaran tampak sepenuhnya sukarela, seseorang masih dapat berbicara tentang perekrutan karena tekanan besar diberikan pada otoritas lokal untuk memobilisasi penduduk untuk tujuan ini. Nasib para romusha ini ternyata menyedihkan, seringkali lebih buruk daripada nasib para tawanan perang. Seringkali dibiarkan sendirian oleh orang Jepang, mereka menjadi korban kelaparan dan penyakit dan, jika mereka masih hidup, ditemukan kurus kering oleh para pembebas. Penduduk asli terlihat meninggalkan kampung dan menaiki kapal di Semarang.

5) Nampo Hodo (20) yang terbit pada 1 January 1944. Film propaganda ini berdurasi sekitar 6 menit dengan produsernya Berita Film di Djawa Film propaganda ini berisi tentang berita dari masa pendudukan Jepang, di mana orang Indonesia dipanggil untuk menjadi sukarelawan bagi Jepang dan 'membebaskan negaranya sendiri'. Seorang petugas informasi memberikan pidato, diikuti dengan parade dengan musik dari heiho dan relawan. Sukarno dan Hatta memimpin pawai. Banyak relawan terlihat membangun lapangan terbang militer. 
Dengan adanya video arsip tersebut diharapkan pembelajaran sejarah dengan tema masa pendudukan Jepang dapat menjadi lebih baik. Peserta didik dapat mengkaji video tersebut dengan menggunakan model pembelajaran video base learning atau problem base learning, sehingga menemukan bagaimana dan seperti apa kehidupan masyarakat Indonesia pada masa pendudukan Jepang, selain itu bagaimana upaya Jepang terkait propagandanya untuk memobilisasi penduduk Indonesia dapat dilihat dari video arsip tersebut. Banyak variasi dan jenis dari video arsip yang dapat dimanfaatkan sebagai media pembelajaran sejarah baik itu bersifat drama, dokudrama, atau dokumenter. Proses belajar mengajar dengan menggunakan media ini menjadi bervariasi, menyenangkan, mudah dipahami, mampu merangsang imajinasi, mengkongkritkan peristiwa yang sebelumnya abstrak dalam waktu singkat dan dapat membawa peserta didik menembus ruang dan waktu. Hal ini dapat membantu peserta didik dalam meningkatkan hasil belajar, terlebih tren pembelajaran dengan menggunakan teknologi digital yang terdapat pada unsur keterampilan abad 21 tengah diminati (Husmiati, 2017).

Berbagai lembaga pendidikan berusaha melatih anak didiknya untuk menguasai keterampilan abda 21 . Keterampilan tersebut diistilahkan dengan $4 \mathrm{C}$ yang merupakan singkatan dari Critical Thinking atau berpikir kritis terhadap suatu permasalahan, Collaboration atau bekerjasama dengan sesama, Communication kemampuan berkomunikasi antar peserta didik, dan Creativity atau kreativitas. Hal ini sejalan dengan US-based Partnership for 21st Century Skill (P21) mengemukakan bahwa kompetensi yang harus dimiliki oleh sumber daya manusia di abad 21 adalah: ketrampilanberpikir kritis (Critical Thinking Skills), keterampilan berpikir kreatif/kreativitas (Creative Thinking Skills), keterampilan komunikasi (Communication Skills), dan keterampilan kolaborasi (Collaboration Skills) (Arnyana, 2019).

Pendidikan pada masa digital sudah memasuki era revolusi industri 4.0 yang tidak terbatas hanya pada kelas saja. Ruag dan waktu pada masa sekarang sudah berjalan sejajar dengan pendidikan demi mewujudkan indovidu yang modern dan bergerak sesuai dengan perkembangan zaman. Pemanfaatan era digitalisasi terdapat teknologi yang berkembang tanpa menjadikan hambatan dalam proses pembelajaran. Salah satunya video based learning, pembelajaran berbasis video tidak tergantung dalam ruang dan waktu, dan bisa di atur sesuai kebutuhan dalam pembelajaran. Penggunaan video sebagai media pembelajaran banyak di lakukan dalam berbagai kegiatan seperti seminar, diskusi dan sejenisnya (Maulida dkk., 2020)

Video base learning adalah model yang menyajikan pesan audio visual, bahasa, prosedur, teori aplikasi untuk membantu pemahaman. Menurut Rhonchetti (2010), keuntungan utama dalam penggunaan video dalam kuliah adalah untuk membantu kerja mahasiswa dengan menjembatani kesenjangan yang diberikan oleh ketidakhadiran mereka selama kuliah reguler, mendukung mahasiswa reguler dengan memberikan kesempatan untuk memulihkan kuliah yang hilang, membantu mahasiswa yang mengalami kesulitan dengan kuliah bahasa lisan, dan memberi mahasiswa tujuan untuk meninjau bagian kritis dan memeriksa catatan mereka (Nur dkk., 2019) 
Dalam penggunaan video base learning, dapat di kolaborasikan dengan model pembelajaran lainnya seperti problem base learning untuk dapat memberikan konstruksi sebuah peristiwa sejarah melalui pengamatan arsip film propaganda masa pendudukan Jepang. Kontruksi pembelajaran sejarah ini dilakukan dengan menghadirkan permasalahan yang kompleks dan realistik terhadap mahasiswa terkait tema arsip film propaganda masa pendudukan Jepang yang telah disediakan. Dengan demikian pembelajaran dalam mencari fakta sejarah akan memunculkan kolerasi dengan pengetahuan mahasiswa mengenai sejarah pendudukan Jepang di Indonesia terkait propaganda romusha. Cakupan dari pembelajaran sejarah akan semakin luas, tidak saja pada tokoh-tokoh besar namun juga mengenai peran rakyat jelata dan sampai menyentuh sejarah lokal. Menurut Amir (2015) Problem Based Learning terdiri dari tujuh langkah yaitu sebagai berikut: (1) Mengklarifikasikan istilah dan konsep; (2) Merumuskan masalah; (3) Menganalisis masalah atau proses pengkomunikasian mengenai konsep ataupun penyelesaian suatu masalah; (4) Menata gagasan secara sistematis dan menganalisisnya dengan dalam; (5) Memformulasikan tujuan pembelajaran;(6) Mencari informasi tambahan dari sumber lain (diluar diskusi kelompok); (7) Mensintesa (menggabungkan) dan menguji informasi baru, dan membuat laporan analisis. Dengan langkah-langkah diatas maka kemampuan berfikir kritis dapat dikembangkan melalui Problem base learning antara lain dengan mengklarifikasi, mengasumsi, memprediksi, menghipotesis, menganalisis, dan membuat kesimpulan serta mengevaluasi (Mujyati \& Sumiyatun, 2016)

\section{SIMPULAN}

Pendudukan Jepang dengan propagandanya merupakan hal menarik yang layak untuk dikaji. Video-video propaganda yang awalnya tidak bisa diakses secara terbuka, menjadikan pembelajaran terkait masa pendudukan Jepang dengan taktik propaganda untuk memobilisasi bangsa Indonesia kurang maksimal. Dengan akses terbuka dari Nederlands Instituut voor Beeld en Geluid yang merupakan arsip budaya dan sebuah museum, pengajar dapat memanfaatkan akses tersebut untuk memberikan meteri kepada peserta didik terkait masa pendudukan Jepang dengan propagandanya melalui film. Perkembangan teknologi yang pesat mendorong manusia berfikir praktis dan serba efisien. Pendidikan juga harus dapat mengimbangi perkembangan teknologi tersebut. Sebagai pengajar sejarah perkembangan teknologi bukanlah sebuah hambatan, namun sebuah peluang yang tepat untuk merubah kesan bahwa sejarah adalah mata pelajaran yang membosankan. Dengan menggunakan video arsip sebagai media dan sumber belajar peserta didik diharapkan dapat mewujudkan proses belajar mengajar menjadi bervariasi, dan dapat merekronstruksikan peristiwa masa lalu dengan tepat. Penggunaan model pembelajaran video base learning dan problem base learning diharapkan dapat meningkatkan daya kritis dari mahasiswa dengan mangamati dan menganalisis film arsip terkaiat propaganda pada masa pendudukan Jepang.

\section{DAFTAR RUJUKAN}

Arsip film koleksi Open Belden https://www.openbeelden.nl/ diakses bulan Oktober 2020- Januari 2021 
Nampo Hodo (20) “Kita Madjoe, Mesoeh Merana!, Kita Menjerboe Moesoeh Binasa! produksi pada 1 January 1944

Nippon Eigasja “Barisan Pekerdja” produksi pada 1 Januari 1943

Nippon Eigasja “Bekerdja” produkdi pada 1 Januari 1943

Nippon Eigasja “Disnipoen medan perang (5)” produksi pada 1 Januari 1943

Nippon Eigasja “Disnipoen medan perang (6)” produksi pada 1 Januari 1943

Buku

Adams, C. (2014). Bung Karno Penyambung Lidah Rakyat Indonesia. Jakarta: Yayasan Bung Karno dan Media Presindo

Amir, M. T. 2015. Inovasi Pendidikan Melalui Problem Based Learning Bagaimana Pendidik Memberdayakan Pemelajar di Era Pendidikan. Jakarta: Kencana.

Benda, H. J. (1958). The Crescent and the Rising Sun: Indonesian Islam under the Japanese Occupation 1942-1945. The Hague van Hoeve.

Hutari, F. (2009). Sandiwara dan Perang: Politisasi Terhadap Aktifitas Sandiwara Modern Masa Jepang. Yogyakarta: Ombak.

Kasenda, P. (2015). Soekarno dibawah Bendera Jepang (1942-1945). Jakarta: Kompas

Kurasawa, A. (1993). Mobilisasi dan Kontrol: Studi Tentang Perubahan Sosial di Pedesaan Jawa 19421945. Jakarta: Grasindo.

Kurasawa, A. (2016). Masyarakat dan Perang Asia Timur Raya: Sejarah dengan Foto yang Tak Terceritakan. Depok: Komunitas Bambu.

Sofansyah, D.Y. (2018). Propaganda Romusha Sandiwara dari Jepang. Yogyakarta: Mata padi Jurnal

Absor, U. (2017). Religious Archives : Peran Arsip Dan Dokumentasi Dalam Penulisan Sejarah. Jurnal Kajian Islam Interdisipliner, 2(1), 57-70. http://ejournal.uinsuka.ac.id/pasca/jkii/article/view/1082/17\#

Afiyanti, Y. (2014). Penggunaan Literatur Dalam Penelitian Kualitatif. Jurnal Keperawatan Indonesia, 9(1), 2003-2006. https://doi.org/10.7454/jki.vgi1.157

Alfian, M. (2011). Pendidikan Sejarah dan Permasalahan yang dihadapi. Khazanah Pendidikan, 3(2).

Aman, A. (2011). Di Seputar Sejarah dan Pendidikan Sejarah. Informasi, 37(1), 26-41. https://doi.org/10.21831/informasi.v111.4461

Arnyana, I. B. P. (2019, February). Pembelajaran Sains di Era Revolusi Industri 4.0. In Prosiding Seminar Nasional MIPA (Vol. 8).

Aryani, D. (2017). Pengelolaan Arsip Film oleh Swasta dan Jaminan Akses Publik. Pakuan Law Review, 3(2), 59-73. 
Dewi, F. P., Setyanto, A., \& Ambarastuti, R. D. (2015). Bentuk Propaganda Jepang Di Bidang Sastra Pada Majalah Djawa Baroe Semasa Kependudukan Jepang Di Indonesia 1942-1945. Jurnal Ilmiah Aurora, 2(1), 47-59.

Erwantoro, H. (2010). Sejarah Sensor Film di Indonesia Masa Hindia Belanda dan Pendudukan Jepang (1916 - 1945). Patanjala: Jurnal Penelitian Sejarah dan Budaya, 2(1), 1. https://doi.org/10.30959/patanjala.v2i1.192

Fadilla, N. (2020). Pendayagunaan Arsip Film Melalui Kegiatan Pemutaran Film Keragaman Lokal Konten Sebagai Pelestarian Nilai Sejarah dan Budaya Jawa. JPUA: Jurnal Perpustakaan Universitas Airlangga: Media Informasi dan Komunikasi Kepustakawanan, 10(2), 128-137.

Husmiati, R. (2017). Kelebihan dan Kelemahan Media Film sebagai Media Pembelajaran Sejarah. Jurnal Sejarah Lontar, 7(2): 61-72. https://doi.org/10.21009/lontar.072.06

Mujyati, N., \& Sumiyatun, S. (2016). Kontruksi pembelajaran sejarah melalui problem based learning (pbl). HISTORIA: Jurnal Program Studi Pendidikan Sejarah, 4(2), 81-90.

Nur, B., Nurdiana, S., \& Nurhalwa. (2019). Video Based Learning sebagai Media Belajar Biologi Jarak Jauh Masa Kini. Seminar Nasional Biologi Dan Pembelajarannya Universitas Negeri Makassar, 229.

Pramudyo, A. (2016). Peran Manajemen Kearsipan Dalam Kehidupan Organisasi. Jurnal Bisnis, Manajemen, dan Akuntansi, 3(2).

Putry, H. M. E., Nuzulul'Adila, V., Sholeha, R., \& Hilmi, D. (2020). Video Based Learning Sebagai Tren Media Pembelajaran Di Era 4.0. Tarbiyatuna: Jurnal Pendidikan Ilmiah, 5(1), 1-24.

Ronchetti, M. (2010). Using video lectures to make teaching more interactive. International Journal of Emerging Technologies in Learning (iJET), 5(2), 45-48.

Santosa, H. Inovasi Pendayagunaan Arsip Melalui Film Dokumenter sebagai Media Edukasi. Khazanah: Jurnal Pengembangan Kearsipan, 12(2), 100-119.

Saputra, A. (2018). Menapaki Kembali Sejarah. Jurnal Renaissance, 3(02), 419-432.

Susilo, J. (2016). Peran dan Fungsi Pendidikan Bahasa Indonesia dalam Mencapai Tujuan Pendidikan Nasional. Seminar Nasional Pendidikan Serentak Se-Indonesia, 1-11.

Yuliati, D. (2012). Mewaspadai Propaganda Melalui Kajian Sejarah (Studi Atas Sistem Propaganda Jepang Di Jawa 1942-1945). Humanika, 15(9). 